\author{
V.A. Protsenko, M.V. Babiy, V.A. Nastasenko \\ Kherson State Maritime Academy, Ukraine \\ (E-mail: ESEU@ukr.net)
}

\title{
Mathematical modeling of the roller-rope coupling operation in misalignment conditions
}

\begin{abstract}
The article deals with the results of construction and mathematical modeling of rope-roller coupling in condition of radial misalignment. As a result of modeling, the operation of coupling is revealed in the presence of misalignment of the shafts connected by it. Formulas are obtained that allow to determine the elongation of the rope depending on the magnitude of misalignment, as well as the design parameters of the coupling. The results of the investigations also allow determining the radial load from the coupling on the shafts at any angle of rotation of the coupling. Numerical simulation by the obtained formulas made it possible to establish that coupling is characterized by high compensating ability and low radial stiffness. So, with a radial displacement of $0.5 \mathrm{~mm}$ (for a prototype coupling with elastic star allow only $0.25 \mathrm{~mm}$ ), the rope-roller coupling creates a load of only $5 \mathrm{~N}$ on the shafts, with a rope elongation of $5.5 \mu \mathrm{m}$. The dependencies obtained are approved during the design of the coupling, and the results of the calculations on them are checked by comparison with the results of the construction and showed a coincidence. The obtained results can be used in the design of rope-roller couplings.
\end{abstract}

Keywords: mathematical model, misalignment, coupling, rope, load, tightening.

\section{Introduction}

For the declared prospects of any design, a specific input can be obtained by performing an experimental or calculated study of its parameters and characteristics. For couplings, the most important indicator is the compensating capacity, which is characterized by the force of the coupling on the shafts - the radial load, which connects the radial stiffness of the coupling and the radial misalignment $\Delta_{r}$. Therefore, the estimation of the radial load on the shafts from the coupling during its operation under misalignment conditions is an actual task. Determination of the load from the coupling to the shafts, in turn, is impossible without determining the deformation of the elastic link of the coupling.

\section{Statement of the research task}

Researching coupling shown on Figure 1. It contains two half-couplings - the external (1) and the internal (2), which are joined by a segment of the rope (3), which may be several, both ends (4) and (5) of the rope (3) are fixed in the pins (6), which are installed in the external half-coupling (1), and the internal half-coupling (2) contains the rollers (8) installed with the possibility of turning on the axes (7), between which there is a rope (3) that covers the rollers (8).

The coupling works as follows. When rotating by the actuator of the external half-coupling (1), with it, the pins (6) are rotated causing the tension of the rope (3). The tensioned rope (3), covering the rollers (8), is actually presses on them and on the axis (7), creating a torque on the driven internal half-coupling (2) and rotating it. In the event of misalignment of the half couplings (1) and (2), the rollers 8 of the driven half-coupling (2) shall be rolled up along the rope (3), due to which the compensation of misalignment will occur. In the case of in-line arrangement of the half-coupling the rollers (8) will not rotate along the rope (3).

The rope 3 of the coupling is blown by air when the coupling is rotated, and when the rope is destroyed, halfcouplings have the possibility of a non-impact relative rotation due to the difference in their outer diameters. The coupling parts have simple configuration and do not require precise machining, they can be made on a lathe, even in ship conditions. Replacing the rope (3) is not a problem - just unscrew the two screws that fix its ends (4) and in (5) in the pins (6).

Determination of the deformation of the elastic link of the rope-roller coupling for calculating the radial load from the coupling to the shafts when operating under misalignment is the purpose of this article. 

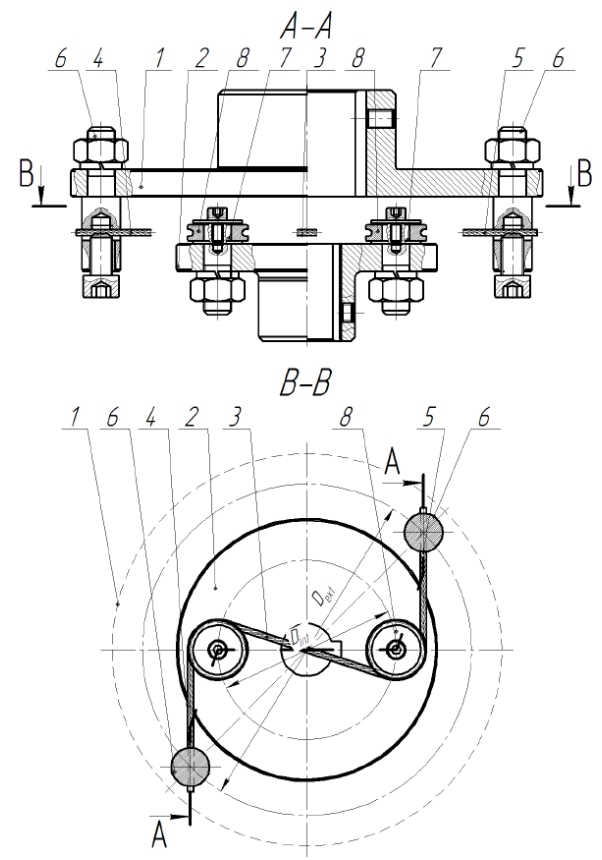

Figure 1. General scheme of roller-rope coupling

\section{Statement of the main material}

Lets consider the operation of the coupling in the conditions of radial misalignment $\Delta_{r}$. In this the centre of driven half-coupling in which fixed the centre of the rollers (Fig. 2) will shift by $\Delta_{r}$ from point $O$ to point $O_{1}$. In this while coupling rotating range of distances are changing - $A B, S A$, arc $S R$ by changing the articles за рахунок зміни кутів $\beta_{1}, \beta_{2}, \beta_{4}-\beta_{7}$ and the angle of the mounting displacement of the half-couplings $\xi$.

Points on the calculating scheme, which are relate to roller and rope and lays over radial displacement plane (plane in which both axes of displaced shafts lay) are denoted by an index 1, and those points, which lays under the plane of radial displacement - by an index 2. Respectively angles are denoted by one and two dashes. In this way rope section $O_{1} R_{1} S_{1} A_{1}$,

which situated over the radial displacement plane, became longer than section $O_{1} R_{2} S_{2} A_{2}$ under those plane by increasing the length of section $S_{1} A_{1}$ in comparison with $3 S_{2} A_{2}$ and arc $R_{1} S_{1}$ in comparison with $R_{2} S_{2}$ (increasing the roller reach angle $\beta_{2}^{\prime}$ in comparison with angle $\beta_{2}^{/ /}$).

For rope elongation determination and respectively load on shafts from coupling in present of radial misalignment $\Delta_{r}$ it necessary to determinate rope length in that conditions. This task is reducing to determination of mentioned sections $O_{1} R_{1} S_{1} A_{1}$ and $O_{1} R_{2} S_{2} A_{2}$ length and respectively angles $\beta_{2}^{\prime}=\beta_{5}^{\prime}+\beta_{6}^{\prime}+\beta_{7}^{\prime}$ and $\beta_{2}^{/ /}=\beta_{5}^{\text {/I }}+\beta_{6}^{\text {/I }}+\beta_{7}^{\text {//. }}$.

To find this angles we need to determinate also reduced mounting displacement angles $\xi_{1}^{\prime}$ and $\xi_{2}^{\prime}$. It is necessary to determinate all parameters depending of coupling rotation angle relatively of radial displacement plane. 


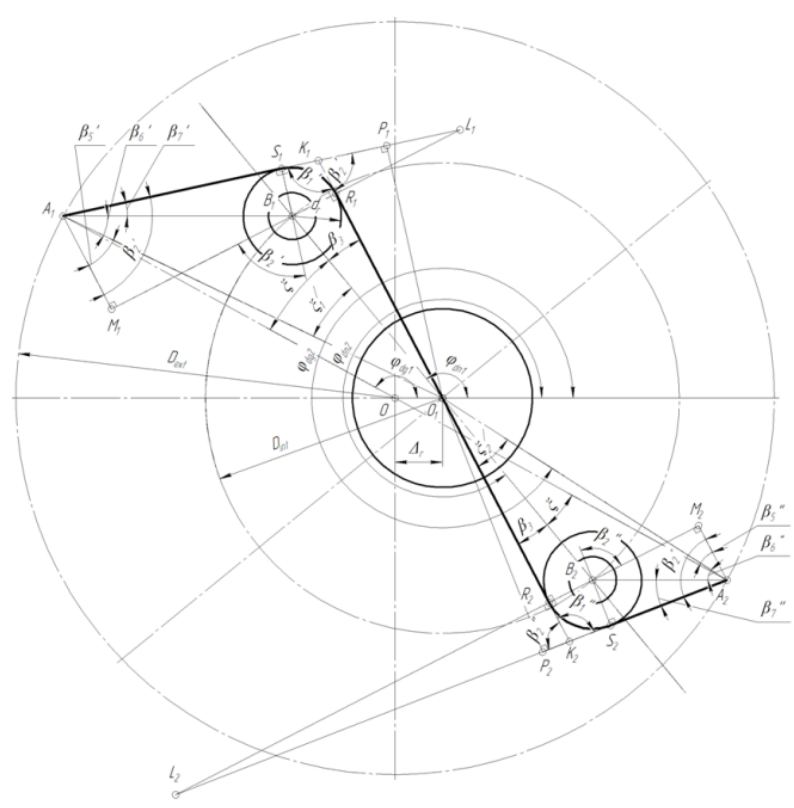

Figure 2. Scheme to geometric calculation coupling

On the firs stage we will show connection with rotation angles $\varphi_{d g}$ of driving half-coupling and $\varphi_{d n}$ of driven half-coupling when operation of radial displacement conditions. For this let's consider the scheme shown on Figure 3.

Let's consider coupling position in which sections $A B$ are parallel to radial displacement plane (Fig. 3). Triangles $O A_{1} C_{1}$ and $O_{1} B_{1} C_{3}$ are giving the opportunity to obtain formulas for angle coordinates the roller centre point $B$ and the point $\mathrm{A}$ of rope end anchoring in this position.

$$
\cos \chi=\frac{O_{1} C_{3}}{O_{1} B_{1}}=\frac{h}{0,5 D_{\text {int }}},
$$

where $h-$ triangle $O A_{1} C_{1}$ height.

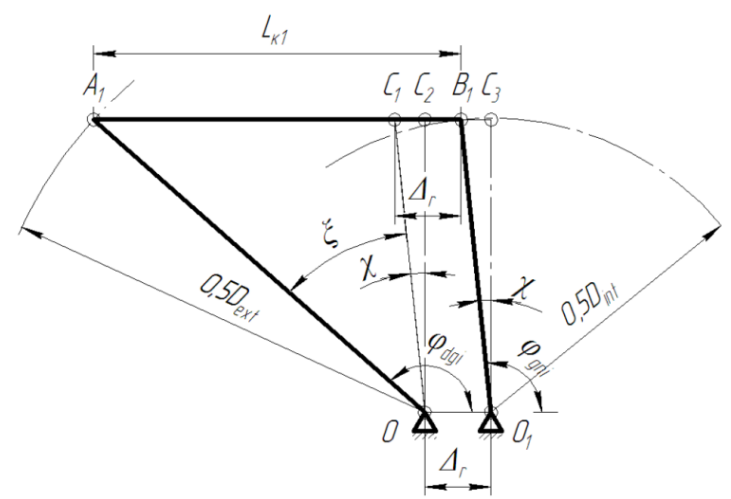

Figure 3. Scheme to calculation of angle coordinate coupling elements

Withal, writing formula for triangle $O A_{1} C_{1}$ like a half of area parallelogram, built on sides $O A_{1}$ and $O C_{1}$ :

$$
h=\frac{2 S_{O A_{1} C_{1}}}{A_{1} C_{1}}=\frac{2 \times 0,5 \times O A_{1} \times O C_{1} \times \sin \xi}{L_{\kappa 0}}=\frac{0,25 D_{e x t} D_{i n t} \sin \xi}{L_{\kappa 0}},
$$

where $L_{\mathrm{K} 0}$ - the original rope length without radial displacement influence.

With considering (1) and (2) we obtain:

$$
\cos \chi=\frac{0,5 D_{3 \mathrm{~B}} \sin \xi}{L_{\mathrm{K} 0}}
$$


Than expressions for obtaining angle coordinates in that position will have the form:

$$
\begin{gathered}
\varphi_{d g 1}=\frac{\pi}{2}+\chi+\xi=\frac{\pi}{2}+\arccos \frac{0,5 D_{e x t} \sin \xi}{L_{A B}}+\xi ; \\
\varphi_{d n 1}=\frac{\pi}{2}+\chi=\frac{\pi}{2}+\arccos \frac{0,5 D_{e x t} \sin \xi}{L_{A B}} \\
\varphi_{d g i}-\varphi_{d n i}=\xi .
\end{gathered}
$$

The problem of finding section $A B$ length in each position we shall solve by method closed vector circuits of prof. V.A. Zinoviev [1, 2]. For obtaining further calculation lets imagine kinematic scheme of replacement mechanism in the form of a closed vector circuit $A O O_{1} B$ (Fig. 4), for which we can write vector equation:

$$
\vec{V}_{1}+\vec{V}_{2}=\vec{V}_{3}+\vec{V}_{4}
$$

where $\vec{V}_{1}=O A-$ driving half coupling radius; $\vec{V}_{2}=L-$ distance between A and B points; $\vec{V}_{3}=\Delta_{r}-$ radial misalignment; $\vec{V}_{4}=O_{1} B-$ driven half coupling radius.

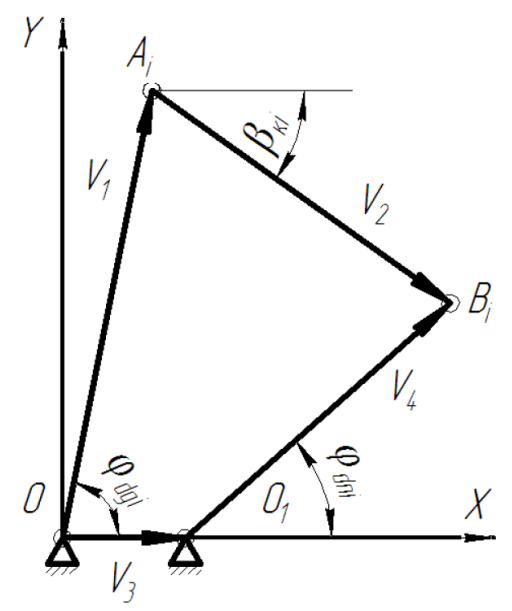

Figure 4. Scheme of closed vector circuit replacement mechanism

The resulting equation (7) I projections on coordinate axes will have the form of a equation system (8):

$$
\left\{\begin{array}{l}
X: V_{1} \cos \varphi_{d g i}+V_{2} \cos \beta_{\kappa i}=V_{3} \cos 0+V_{4} \cos \varphi_{d n i} \\
Y: V_{1} \sin \varphi_{d g i}+V_{2} \sin \beta_{\kappa i}=V_{3} \sin 0+V_{4} \sin \varphi_{d n i}
\end{array}\right.
$$

After the transformation we obtain:

$$
\left\{\begin{array}{l}
V_{2} \cos \beta_{\kappa} i=V_{3}+V_{4} \cos \varphi_{d n i}-V_{1} \cos \varphi_{d g i} \\
V_{2} \sin \beta_{\kappa} i=V_{4} \sin \varphi_{d n i}-V_{1} \sin \varphi_{d g i}
\end{array} .\right.
$$

Square both equations (9) and add them, where after transformation we obtain:

$$
\begin{gathered}
V_{2}^{2}\left(\cos ^{2} \varphi_{\kappa i}+\sin ^{2} \varphi_{\kappa i}\right)=\left(V_{3}+V_{4} \cos \varphi_{d n i}-V_{1} \cos \varphi_{d g i}\right)^{2}+\left(V_{4} \sin \varphi_{d n i}-V_{1} \sin \varphi_{d g i}\right)^{2} \\
V_{2}=\sqrt{\left(V_{3}+V_{4} \cos \varphi_{d n i}-V_{1} \cos \varphi_{d g i}\right)^{2}+\left(V_{4} \sin \varphi_{d n i}-V_{1} \sin \varphi_{d g i}\right)^{2}}
\end{gathered}
$$

Whence distance $A B$ in any coupling position will be:

$$
L_{A_{i} B_{i}}=\sqrt{\left[\Delta_{r}+0,5 D_{e x t}\left(\cos \varphi_{d n i}-\cos \varphi_{d g i}\right)\right]^{2}+\left[0,5 D_{e x t}\left(\sin \varphi_{d n i}-\sin \varphi_{d g i}\right)\right]^{2}} .
$$

Returning to the Figure 3, from triangle $O A_{1} O_{1}$ we can wrote:

$$
A_{1} O_{1}=\sqrt{O O_{1}^{2}+O A_{1}^{2}-2 \times O O_{1} \times O A_{1} \cos \varphi_{d g 1}} ;
$$




$$
\begin{aligned}
& L_{A_{1} O_{1}}=\sqrt{\Delta_{r}^{2}+0,25 D_{e x t}^{2}-\Delta_{r} D_{e x t} \cos \varphi_{d g 1}} ; \\
& L_{A_{i} O_{i}}=\sqrt{\Delta_{r}^{2}+0,25 D_{e x t}^{2}-\Delta_{r} D_{e x t} \cos \varphi_{d g i}} .
\end{aligned}
$$

From triangle $O_{1} A_{1} B_{1}$ by the cosine theorem we have:

$$
A_{1} B_{1}^{2}=A_{1} O_{1}^{2}+O_{1} B_{1}^{2}-2 \times A_{1} O_{1} \times O_{1} B_{1} \cos \xi_{1}^{\prime},
$$

whence we obtain:

$$
\begin{gathered}
\xi_{1}^{\prime}=\arccos \left[\frac{A_{1} O_{1}^{2}+O_{1} B_{1}^{2}-A_{1} B_{1}^{2}}{2 \times A_{1} O_{1} \times O_{1} B_{1}}\right] ; \\
\xi_{1}^{\prime}=\arccos \left[\frac{L_{A_{1} O_{1}}^{2}+0,25 D_{\text {вн }}^{2}-L_{A_{1} B_{1}}^{2}}{L_{A_{1} O_{1}} D_{\text {вн }}}\right] ;
\end{gathered}
$$

or in general form

$$
\xi_{i}^{\prime}=\arccos \left[\frac{L_{A_{i} O_{i}}^{2}+0,25 D_{i n t}^{2}-L_{A_{i} B_{i}}^{2}}{L_{A_{i} O_{i}} D_{i n t}}\right] .
$$

Next we can use obtained earlier equations (16), (17), (19)-(21) substituting in place of angle $\xi$ reduced mounting displacement angle $\xi_{i}^{\prime}$.

$$
\begin{gathered}
\beta_{2}^{i}=\xi_{i}^{\prime}+\beta_{3}+\beta_{6}^{i}+\beta_{7}^{i}= \\
=\xi_{i}^{\prime}+\arcsin \frac{d_{r}}{D_{\mathrm{int}}}+\arcsin \left(\frac{0,5 D_{\mathrm{int}}}{L_{A_{i} B_{i}}} \sin \xi_{i}^{\prime}\right)+\arcsin \left(\frac{0,5 d_{r}}{L_{A_{i} B_{i}}}\right), \\
\beta_{1}^{V}=180-\beta_{2}^{V},
\end{gathered}
$$

where $d_{r}$ - roller diameter.

Respectively rope length in each position of coupling will be:

$$
L_{r \Delta}=L_{r 1}+L_{r 2},
$$

where $L_{r 1}=S_{1} A_{1}+R_{1} S_{1}+O_{1} R_{1}$ - the length of a rope section under radial displacement plane;

$L_{r 2}=S_{2} A_{2}+R_{2} S_{2}+O_{2} R_{2}$ - the length of a rope section over radial displacement plane, where

$$
\begin{gathered}
S_{i} A_{i}=A_{i} B_{i} \cos \beta_{7}=L_{A_{i_{B}}} \cos \left(\arcsin \frac{0,5 d_{r}}{L_{A_{i}} B_{i}}\right) ; \\
R_{i} S_{i}=\frac{\pi d_{r}}{360} \beta_{2}^{i} ; \\
O_{1} R_{1}=O_{2} R_{2}=0,5 D_{\text {int }} \cos \beta_{3}=0,5 D_{\text {int }} \cos \left(\arcsin \frac{d_{r}}{D_{\text {int }}}\right) .
\end{gathered}
$$

Rope elongation $\Delta L_{r}$ in relatively with rope length $L_{r}$ in coupling without radial displacement:

$$
\begin{gathered}
\Delta L_{r}=L_{r \Delta}-L_{r} ; \\
L_{r}=2\left(0,5 D_{\text {int }} \cos \beta_{3}+\frac{\pi d_{r}}{360} \beta_{2}+L_{A B} \cos \beta_{7}\right) .
\end{gathered}
$$

Radial load on shafts for rope elongation will be:

$$
F_{\text {rad }}=A_{\Sigma} E_{r} \frac{\Delta L_{r}}{L_{r}}
$$

where $A_{\Sigma}$ - total area of wires cross section in rope; $E_{p}=1,0 \times 10^{5} \mathrm{MPa}$ - rope tensile modulus [3].

For illustration of obtained results modeling of real coupling operation done. The parameters of coupling were following: $D_{\text {ext }}=120 \mathrm{~mm}, D_{i n t}=65 \mathrm{~mm}, d_{r}=20 \mathrm{~mm}, \xi=45^{\circ}$. Rope length in absence radial displacement, 
calculated with obtained earlier equation is $L_{r}=184,37 \mathrm{~mm}$. Force calculation, made with methodic, developed earlier, show that strength condition corresponds rope with construction $6 \times 7(1+6)$ GOST 3069 with diameter $d_{r}=2,2 \mathrm{~mm}$ with total area of wires cross section in $A_{\Sigma}=1,64 \mathrm{~mm}^{2}$. Radial misalignment for clarity $\Delta_{r}=0,5$ $\mathrm{mm}$ - twice as much as allowed radial displacement for prototype coupling ROTEX SIZE $28\left[\Delta_{r}\right]=0,25 \mathrm{~mm}$. Angle of rotation $\mathrm{Jp}$. varied in range $0 \ldots 360^{\circ}$ across $30^{\circ}$, respectively angles of location coupling elements were calculate of formulas:

$$
\begin{gathered}
\varphi_{d g 1 i}=\varphi_{i} ; \\
\varphi_{d n 1 i}=\varphi_{i}-\xi ; \\
\varphi_{d g 2 i}=\varphi_{d g 1 i}+\pi ; \\
\varphi_{d n 2 i}=\varphi_{d n 2 i}+\pi .
\end{gathered}
$$

Whence with equation (12) determinate in each position distances $L_{A_{1} B_{1}}$ and $L_{A_{2} B_{2}}$, with equation (13) distances $L_{A_{1} O_{1}}$ and $L_{A_{2} O_{2}}$, that with equation (15) reduced mounting displacement angles $\xi_{1}^{\prime}$ та $\xi_{2}^{\prime}$, and also angles $\beta_{2}^{/}, \beta_{2}^{/ /}, \beta_{1}^{\prime}, \beta_{1}^{/ /}$, and respectively rope length $L_{r}$ for coaxial (23) and desaxial $L_{r \Delta}(18)$ coupling, rope elongation $\Delta L_{r}(22)$, and radial load $F_{\text {rad }}$ from coupling on shafts $(24)$.

Results of modeling are illustrated by Figure 5. From this figure we can make following conclusions. Rope elongation and radial load changing occurs under the asymmetric constant-sign law. In this maximal rope elongation is $0.0055 \mathrm{~mm}$ which is 9 times less than radial misalignment $\Delta_{r}$ in modeling. Calculated radial load in this conditions is only $5 \mathrm{~N}$, which illustrating high compensating ability of new proposed coupling. Therefore in modeling misalignment of $0.5 \mathrm{~mm}$ radial stiffness of new coupling will be nearly $10 \mathrm{~N} / \mathrm{mm}$. The other types of couplings with elastic elements have much higher radial stiffness and making higher radial loads on shafts connected with coupling.

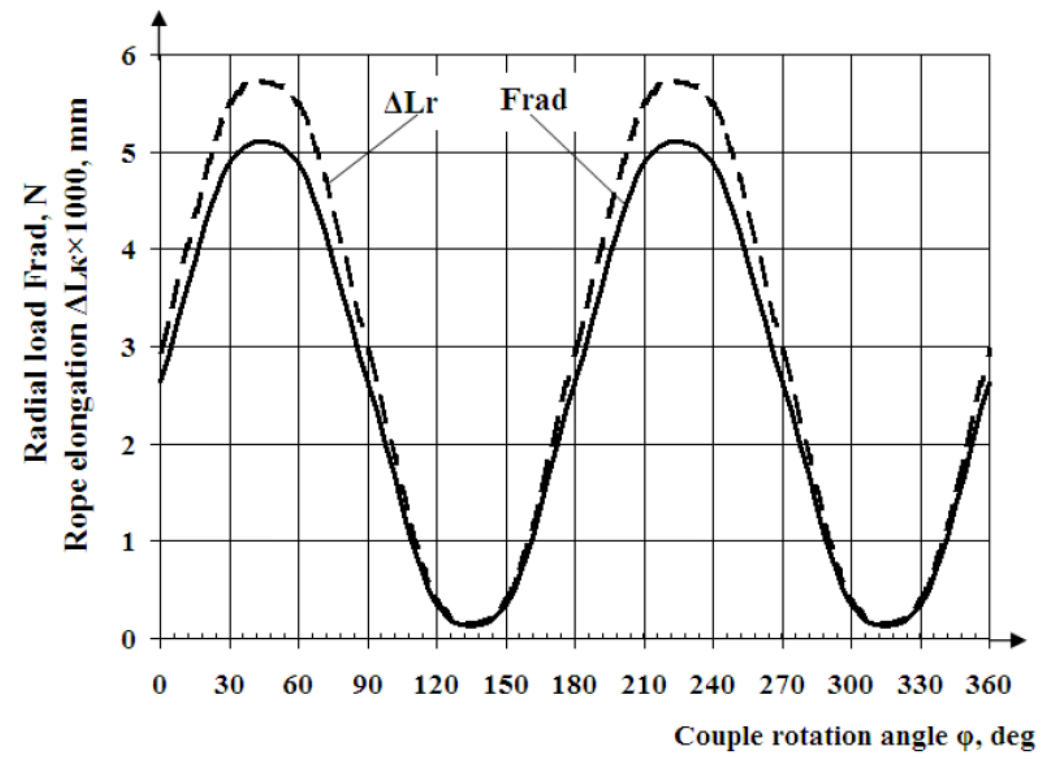

Figure 5. Graph of rope elongation and radial load changing from couple angle of coupling rotation

Done analytical researches allows to make following conclusions:

1. Mathematic model of roller-rope coupling in condition of misalignment made. It allows to calculate rope elongation and radial load on shafts from rope deformation depending on angle of coupling rotation.

2. Rope elongation and radial load changing occurs under the asymmetric constant-sign law and reaches a maximum in position when rope axe $R_{1} R_{2}$ approaching to radial displacement vector $O O_{1}$.

3. Roller-rope coupling construction provides minimal rope elongation and respectively radial load from coupling on shafts. Modeled coupling, for example, in radial misalignment of $0.5 \mathrm{~mm}$ have maximum elongation nearly $0.0055 \mathrm{~mm}$ and making radial load of only $5 \mathrm{~N}$. 
1 Зиновьев Вяч.А. Курс теории механизмов и машин / Вяч.А. Зиновьев. - М.: Физматгиз, 1960. $431 \mathrm{c.}$

2 Артоболевский И.И. Теория механизмов / И.И. Артоболевский. - М.: Наука, 1967. - 719 с.

3 Малиновский В.А. Стальные канаты: аналитический справочник / В.А. Малиновский. - Одесса: Астропринт, 2016. - 252 с.

\title{
В.А. Проценко, М.В. Бабий, В.А. Настасенко
}

\section{Сәйкессіз шартты арқанды-роликті муфтаның жұмысын математикалық моделдеу}

\begin{abstract}
Мақалада радиалды сәйкессіздік жағдайында арқанды-роликті муфтаның конструкциясы, сонымен қатар оның математикалық моделінің жұмысы ұсынылған. Модельдеу нәтижесінде байланыстыратын біліктердің сәйкессіз болғандағы муфта жұмысының процесі анықталды. Сәйкессіздік шамасына қарай арқанның ұзаруын, сондай-ақ муфтаның коструктивті параметрлерін анықтайтын формулалар алынған. Зерттеу нәтижелері муфтаны кез келген бұрышқа бұрағанда муфтадан біліктерге радиалды жүктемені анықтауға мүмкіндік береді. Алынған формулалардың сандық модельдеуі муфтаның жоғары компенсациялық қасиетімен және төмен радиалды қаттылығымен сипатталатынын анықтауға мүмкіндік берді. Радиалды 0,5 мм жылжуда (резеңке жұлдызшасы бар муфта-прототипі үшін 0,25 мм болуы келісілген) арқанның ұзаруы 5,5 мкм болғанда арқанды-роликті муфта біліктерге 5 Н жүктеме жасайды. Алынған тәуелділіктер муфтаны жобалауда апробацияланған, ал есептеу нәтижелері оларды салыстыру арқылы тексеріледі және сәйкестік көрсетті. Алынған нәтижелерді арқанды-роликті муфталарды жобалауда пайдалануға болады.
\end{abstract}

Kiлm сөздер: математикалық модель, сәйкессіздік, муфта, арқан, жүктер, кернеу.

\section{В.А. Проценко, М.В. Бабий, В.А. Настасенко \\ Математическое моделирование работы канатно-роликовой муфты в условиях несоосности}

\begin{abstract}
В статье представлена конструкция канатно-роликовой муфты, а также разработана математическая модель ее работы в условиях радиальной несоосности. В результате моделирования раскрыт процесс работы муфты при наличии несоосности соединяемых ею валов. Получены формулы, позволяющие определить удлинение каната в зависимости от величины несоосности, а также конструктивных параметров муфты. Результаты исследований позволяют также определить радиальную нагрузку от муфты на валы при любом значении угла поворота муфты. Численное моделирование по полученным формулам дало возможность установить, что муфта характеризуется высокой компенсирующей способностью и низкой радиальной жесткостью. Так, при радиальном смещении 0,5 мм (для муфтыпрототипа с резиновой звездочкой допускается 0,25 мм) канатно-роликовая муфта создает на валы нагрузку всего 5 Н при удлинении каната в 5,5 мкм. Полученные зависимости апробированы при проектировании муфты, а результаты расчета по ним сравнены с результатами построения и совпали. Результаты могут быть использованы при проектировании канатно-роликовых муфт.
\end{abstract}

Ключевые слова: математическая модель, несоосность, муфта, канат, нагрузки, натяжение.

\section{References}

1 Zinoviev, V.A. (1960). Kurs teorii mekhanizmov $i$ mashin [Course theory of mechanisms and machines]. Moscow: Fizmathiz [in Russian].

2 Artobolevskiy, I.I. (1967). Teoriia mekhanizmov [Theory of mechanisms]. Moscow: Nauka [in Russian].

3 Malinovskiy, V.A. (2016). Stalnye kanaty [Steel ropes]. Odessa: Astroprint [in Russian]. 